\title{
Local Governors' Turnover and Firms’ Investment Comovement
}

\author{
Zhang: Yin \\ Bingyu Guan: Bingyu \\ School of Economics and Management \\ Beijing University of Technology \\ No. 100 Pingleyuan, Chaoyang District, Beijing \\ China
}

\begin{abstract}
Based on the empirical evidence of all A-share listed companies in China from 2007 to 2015, this paper examines the impact of the replacement of local municipal Party committee secretaries on corporate investment synergy. It is found that the replacement of local Party committee secretaries can significantly increase the investment synergy of enterprises in the same year, which can explain that the impact of the replacement of municipal Party committee secretaries on enterprises is more reflected in the transfer of legal political power. This paper further examines the impact of macro environment and official characteristics on the replacement of municipal Party Secretary and investment synergy. The results show that economic depression enhances the impact of official turnover on investment congruence; the impact of official turnover on investment congruence is significantly reduced in areas with high economic development level and high marketization; when the successor municipal Party secretary is from a professional background of economic management or from a different place, the impact of official turnover on investment congruence is significantly reduced; when the former municipal Party Secretary's whereabouts In the case of abnormal promotion, the influence of official turnover on investment synergy is stronger.
\end{abstract}

Keywords: Official turnover, Investment synergy, macro environment, Official characteristics

JEL: F23DC: A DOI:

\section{Introduction}

Government intervention is considered as an important feature of emerging countries. In transitional China, local governments hold administrative approval, land acquisition, and various investment and financing policies. The continuity of local government officials' policies has had a huge impact on local economic development and corporate investment and financing behavior (Zhou Li'an, 2007). Scholars represented by North and other new institutional economics believe that the institutional environment will have an important impact on corporate behavior, and government policies and systems have played a fundamental role in regulating corporate behavior (Fan, Wei and Xu, 2011). In recent years, the research on the replacement of government officials has attracted the attention of many scholars, which has helped to reveal the "black box" of government intervention in enterprises and understand the motivation of individual officials. Relevant research finds the expenditure and efficiency of the replacement of the party committee secretary and investment (Chen Yanyan and Luo Danglun, 2011; Cao Chunfang, 2013; Julio and Yook, 2012; Xu Yekun, Qian Xianhang, and Li Wei'an, 2013), financing behavior (Cheng Zhe and Bai Yunxia, 2015), cash holdings (Jiang Peng, Wang Wenzhong and Lei Guangyong, 2015), changes in state-owned enterprise officials (Pan Yue, Ning Bo and Xiao Jinli, 2015) are closely linked.

At the same time, the social impact of the change of secretary of the municipal party committee is generally considered to affect investor sentiment. Generally speaking, scholars believe that investor sentiment and emotion will have important effects on investment behavior (Abu Bakar et al., 2014; Siganos et al., 2014), and the more complicated the decision and the uncertainty of the result, the greater the impact of investor sentiment on investment decisions (Shu, 2010). A positive mood can make investors more optimistic and tend to make investment decisions that underestimate risk (Wright and Bower, 1992).

So, if and how does the change of secretary of the municipal party committee affect investor sentiment and behavior? Regarding the impact of the replacement of the secretary of the municipal party committee, there are generally two views: first, from the perspective of the transfer of statutory political power, the new municipal party secretary may implement a more aggressive investment promotion policy based on political performance considerations. 
This is generally considered a good investment opportunity. On the other hand, the discontinuity of government, officials, and policies caused by official turnover has a huge impact on corporate investment behavior (Zhou Li'an, 2007). The uncertainty of the political environment caused by this has led non-state-owned enterprises to tend to avoid risks. Thereby investment levels reduced even more (Xu Yekun, Qian Xianhang, and Li Wei'an, 2013). Third, from the perspective of the transfer of factual political rights, Cao Chunfang (2013) found that the replacement of the municipal party committee secretary led to a reduction in the investment volume and excessive investment of local state-owned enterprises. The main reason that the change of Chinese officials affects corporate investment is not the uncertainty of economic policies caused by the transfer of statutory political rights, but the reduction of local government interference caused by the transfer of de facto political rights.

Based on existing literature, investment sentiment is directly related to the herd effect of investment (Prechter, 2001; Parker and Prechter, 2005; Olson, 2006). If investors believe that the replacement of the municipal party committee secretary has increased investment opportunities for enterprises and the high investment sentiment, it will lead to the herd effect of increased investment; if the political power transfer caused by the municipal party committee secretary replacement is the main factor, the uncertainty of political environment is will make investors subconsciously avoid risks, which will lead to herding effects of reduced investment; however, if the government party 's government interference is reduced due to the transfer of de facto power when the city party secretary changes, the company will be more able to Investment conditions, access to information that is heterogeneous, and herd effects may not exist or be weak.

The purpose of this study is to determine whether the investment behavior of the enterprise has caused the herd effect when the party secretary changed. The more important question is, if the change of the municipal party committee secretary leads to the herd effect of investment, how does the change of government affect the mood of investors? The study found that the year when the secretary of the municipal party committee changed, the investment synergy of the enterprises increased significantly, and when the level of economic development and marketization in the region was high, the impact of the change of the municipal party committee secretary on the investment synergy weakened. We further found that when the replaced municipal Party committee secretary had a professional background in economic management or came from a different place, the investment synergy of enterprises in this area was significantly alleviated. The research contributions of this paper are as follows: First, this paper tests whether the investment synergy between enterprises is affected by the change of officials. This paper uses the discovery of the herd effect of corporate party secretary turnover on corporate investment to verify that the social impact of the municipal party secretary replacement is due to the transfer of political power, effectively alleviating related disputes. Second, from the perspective of investment synergy, it provides new evidence that official turnover affects micro-enterprises. Existing research finds that official turnover has different impacts on the level of investment and investment efficiency at the enterprise level (Chen Yanyan and Luo Danglun, 2012; Cao Chunfang, 2013; Xu Yekun, Qian Xianhang, and Li Wei'an, 2013). Direct explanation of investment behavior at the industry level. Third, this article also adds new evidence to the study of the influence of officials' personal characteristics on micro-enterprises. Previous studies have found that officials with corporate experience and management background have a positive effect on economic growth and industrial restructuring (Zhang Ersheng and Hu Guoliu, 2013), however, there is a lack of evidence on the influence of official backgrounds on micro-enterprises. This article finds that officials with a background in management can better enable the government to play a service role and use the market's regulatory function to influence corporate behavior.

The rest of the paper is arranged as follows: the second section conducts theoretical analysis; the third section is the research design; the fourth section provides descriptive statistics, the main test results and their explanations; the fifth section is the robustness test; the sixth section is the conclusion.

\section{Theoretical analysis and hypothesis}

\subsection{The replacement of the secretary of the municipal party committee and the synergy of corporate investment}

The herd behavior of investment synergy is that investors use less private information and choose to imitate the behavior of other investors (Hwang and Salmon, 2004). From the perspective of academia, the herd effect can be divided into two types: intentional imitation and false imitation (Bikhchandani and Sharma, 2000; Holmes et al., 2013).The intentional herding behavior is derived from the imitation behavior of investors in order to obtain benefits from an environment of asymmetric information, and the nature of this behavior is that investors have information advantages or professional skills. Judging from the information advantage of the investment, when investors do not have the information advantage, they will follow the party with the information advantage. At the same time, the herd effect may also stem from professional considerations, especially the consensus reached among professional investors. 
False herd behavior is the result of accepting the influence of common information in the environment, such as the influence of the homogeneity of some relative information (DeBondt and Teh, 1997). The relative homogeneity of information is the similarity of the received signals or investors have similar capabilities for processing information (Wermers, 1999). Previous studies have shown that regular environmental changes can lead to herd behavior of investments. Investors use information with specific stock characteristics to invest, which will lead to the emergence of a certain investment style.

A large amount of literature in the past found that changes in social activities and social emotions can affect the herd behavior of investment. Olson (2006) believes that social emotions can be transmitted within a certain range. Prechter (2001) believes that in financial markets, social sentiment can affect trends and trends, which can lead to unconscious imitation by investors. Parker and Prechter (2005) found that under certain environmental uncertainties, unconsciously imitating behaviors would promote the formation of certain social emotions, and then determine social behaviors, such as investment or stock prices. Hong et al. (2005) found that fund managers living in the same city in the United States interacted, which prompted them to buy (sell) similar stocks. Examining the change of the municipal party secretary from the transfer of political power may cause changes in many aspects of the corporate environment. Generally speaking, for an enterprise, the replacement of the secretary of the municipal party committee may be an opportunity or a risk for the investment behavior of the enterprise. The reason why the change of the municipal party committee secretary is an opportunity is because the new municipal party committee secretary will often implement the "three fires" in order to highlight personal achievements, leading new investment trends and making it easy for managers of enterprises to identify new investment opportunities. To increase corporate investment synergy. The reason why the change of the municipal party committee secretary is a risk is because during the transition of new and old local powers, the political environment is often unstable and uncertain, and the investment behavior of enterprises is relatively stable and cautious. In China, there will be a motivation of "do not seek merit, but seek nothing", that is, the manager will produce a herd behavior in a crisis environment. When the environment is uncertain, the managers of an enterprise would rather invest less or not invest in better investment opportunities, which is what Keynes (1936) believes is the way managers do things. They would rather lose their credibility due to compliance. Its credibility is derived from a violation of conventions.

Judging from the transfer of de facto power, the change in the investment behavior of the municipal party committee secretary in state-owned enterprises found that the replacement of the municipal party committee secretary has led to a reduction in the amount of local state-owned enterprise investment and excessive investment, indicating that the replacement of the municipal party committee secretary has caused changes in the allocation of resources. He believes that the main reason for the change of Chinese officials affecting corporate investment is not the uncertainty of economic policies caused by the transfer of statutory political rights, but the reduced local government intervention caused by the transfer of de facto political rights (Cao Chunfang, 2013). In this way, enterprises get rid of the government's administrative intervention, and enterprises can autonomously obtain more private information through mutual communication and communication, which can reduce the herd effect of investment.

Hypothesis 1a: Increased synergy in investment caused by the change of secretary of the municipal party committee. Hypothesis 2b: The investment synergy decreases due to the change of secretary of the municipal party committee.

\subsection{Secretary of the municipal party committee, macro environment and corporate investment synergy}

In emerging countries such as China, due to policy, economic, historical, and demographic factors, the economic development level and marketization process of various enterprises are very different (Xia Lijun and Chen Xinyuan, 2007). In some regions, marketization is well developed while in some regions, the level of marketization is very low, and government intervention in enterprises is quite common. In regions with higher levels of economic development, investors have a greater ability to collect information, and market mechanisms play a greater role (Chen et al., 2013). Similarly, in regions with a high level of marketization, the degree of marketization is of great significance to the guidance of corporate behavior, and regions with a high degree of marketization can establish market-oriented legal systems and strong enforcement mechanisms. Morck et al. (2000) found that poor protection of property rights and protection of small and medium shareholders would weaken incentives for investors and reduce investors' motivation to obtain corporate characteristic information, which would increase corporate investment synergy. Therefore, we make the following assumptions:

Hypothesis 2a: On the premise that other conditions are the same, when the level of economic development in the region is high, the positive correlation between the replacement of the municipal party committee secretary and the company's investment synergy is significantly alleviated. 
Hypothesis 2b: On the premise that other conditions are the same, when the level of marketization in the region is high, the positive correlation between the replacement of the secretary of the municipal party committee and the company's investment synergy is significantly eased.

The investment activities of enterprises are closely dependent on the macro environment. The macro environment will ultimately affect the investment behavior of enterprises through the prospects of economic development, financing methods and financing channels. When changes in the political environment affect corporate investment activities, the macro environment will also play a key regulatory role. Chordia and Shivakumar (2003) found that macroeconomic factors related to business cycles can better explain inertial investment strategies. It is generally believed that when the macroeconomic environment is more prosperous, companies will be encouraged to invest more; when the economic environment is depressed, corporate investment behavior is generally more conservative and cautious. Therefore, we make the following assumptions:

Hypothesis 2c: On the premise that other conditions are the same, when the economy is relatively depressed, the positive correlation between the replacement of the party committee secretary and the company's investment synergy is significantly strengthened.

\section{Secretary of the municipal party committee, official characteristics and corporate investment synergy}

China's reform and opening is characterized by gradual decentralization, which has given local governments more power. Local officials hold some of the most important resources, such as administrative approval, land acquisition, loan guarantees, and various policy preferences (Yang Haisheng, Luo Danglun, and Chen Shaoling, 2010). At the same time, the current administrative system leaves local officials a large space of discretion, its behavior preferences and individual characteristics will have a greater impact on micro-enterprise behavior.

After emphasizing the four standards of cadres, education level has also become an important condition for the selection and promotion of cadres. Many local government officials have improved their education and professional knowledge through correspondence, party schools, and on-the-job learning. The literature has examined the impact of the personal characteristics of officials on the macro level. Zhang Ersheng (2010) found that officials with corporate background have a significant positive effect on regional economic growth. Zhang Ersheng and Hu Guoliu (2013) found that officials with an economic background can better promote the upgrading of industrial structure. This shows that officials with corporate experience have a strong ability to grasp specific jobs. After becoming local officials, they have a strong ability to manage the overall situation. Different professional specialties determine the individual's work ability advantages and personal behavior preferences.

From the professional background, the important research theme of economics and management disciplines is how to use the role of the market for economic construction. And according to neoclassical macroeconomic theory, including the viewpoint of the rational anticipation school, the government's macroeconomic responsibility is only to maintain market order and allow the market's price mechanism to fully play its role. Regulate investment, consumption, and credit by the rise and fall of market interest rates and prices Wait, the government should not directly interfere with market price signals and resource allocation in order to reduce cyclical fluctuations, promote economic growth, and increase employment (Lin Yifu, 2007). According to the rational manager learning hypothesis, officials with a background in management education will tend to serve and cultivate an effective market, act in accordance with the laws of the market, and use the role of the market to guide the investment behavior of enterprises. In summary, we make the following assumptions:

Hypothesis 3a: The positive correlation between the replacement of the municipal party committee secretary and the company's investment synergy has been significantly alleviated when the replaced municipal party committee secretary has a background in economic management.

In the personal characteristics of officials, the source and destination of the new municipal party committee secretary will also affect the investment behavior of enterprises. Previous literature only focused on the off-site exchange of government officials to promote economic growth (Zhang Jun and Gao Yuan, 2007) and tend to choose more robust accounting policies (Jin Zhi, 2013). However, the impact of government officials from different sources and destinations on how to obtain investment information is rarely seen from a business perspective. This article believes that investors should be more aware of the governing style of locally promoted officials, and it is more likely to increase the synergy of investment; and they are less aware of officials who have succeeded in different places, which will collect more private information, leading to corporate investment Decline in synergy. From the whereabouts of the previous Municipal Party Secretary, if the way he leaves the region is retirement, punishment or death instead of normal work transfer, then the investment activities of the enterprise will be impacted by greater consistency and easier. Increased synergy in investment. We therefore propose: 
Hypothesis 3b: The positive correlation between the replacement of the municipal Party committee secretary and the company's investment synergy has been significantly alleviated when the secretary of the municipal Party committee has been promoted in a different place.

Hypothesis 3c: When the municipal Party committee secretary who left before the region's replacement left abnormally, the positive correlation between the municipal Party committee secretary's replacement and the company's investment synergy is significantly enhanced.

\section{Research Design}

\subsection{Sample selection and data source}

This article takes A-share listed companies as the research object, and further selects samples according to the following steps: (1) Excluding samples with asset-liability ratio greater than 1, that is, insolvent enterprises; (2) Excluding sample records with main business income less than or equal to zero (3) Exclude ST, * ST and other companies that have been specially treated; (4) In order to eliminate the impact of the company's initial public offering on financial accounting information, exclude data records of the company's IPO year; (5) When calculating corporate investment synergy variables in order to ensure that there are at least 5 companies in the same industry and region in the same year, records that do not meet the conditions are excluded. In addition, in order to eliminate the interference of extreme outliers, Winsorize processing was performed on the continuous variable data of major companies such as investment synergy, scale, asset-liability ratio, etc. at the level of 1\%; finally obtained 2316 observation records of listed companies from 2007 to 2015(unbalanced panel data). In order to minimize the impact of database data errors and missing values, this article combines the raw data of multiple commercial databases. Among them, the three major financial statement data, listing time, location and industry code data are from the Wind database, supplemented with data from the Guotai'an Database (CSMAR) for comparison and supplementation; among them, the replacement data of the Party Secretary of each region (professional background) is based on The database of government officials was manually retrieved and collated.

\subsection{Sample description}

The sample of companies selected in this article involves all A-share listed companies. In order to further observe the sample, we made a descriptive statistical analysis of all companies. Table 1 describes the change of the secretary of the municipal party committee where the listed company is located in different sectors in different years. It can be seen that, due to the change of the leadership of the party members and cadres at the 18th Party Congress in 2012, the replacement records of the municipal party committee secretary in 2012 were significantly higher than in other years; in general, the replacement records of the municipal party committee secretary accounted for about $21 \%$ of the total records, and in each sector The turnover ratio of the Municipal Party Committee Secretary has continued to stabilize.

Table 1 Sample distribution (year-market type-official replacement)

\begin{tabular}{|c|c|c|c|c|c|c|c|c|}
\hline \multirow{2}{*}{$\begin{array}{l}\text { group } \\
\text { year }\end{array}$} & \multicolumn{4}{|c|}{ City Party Secretary changed } & \multicolumn{4}{|c|}{ Municipal Party Committee Secretary has not been replaced } \\
\hline & SME board & motherboard & GEM & total & SME board & motherboard & GEM & total \\
\hline \multirow[t]{2}{*}{2007} & 1 & 61 & 0 & 62 & 2 & 28 & 0 & 30 \\
\hline & $(1.61)$ & (98.39) & $(0.00)$ & $(100.00)$ & $(6.67)$ & (93.33) & $(0.00)$ & $(100.00)$ \\
\hline \multirow[t]{2}{*}{2008} & 7 & 17 & 0 & 24 & 6 & 87 & 0 & 93 \\
\hline & (29.17) & $(70.83)$ & $(0.00)$ & $(100.00)$ & $(6.45)$ & (93.55) & $(0.00)$ & (100.00) \\
\hline \multirow[t]{2}{*}{2009} & 3 & 10 & 0 & 13 & 22 & 91 & 0 & 113 \\
\hline & (23.08) & (76.92) & $(0.00)$ & (100.00) & (19.47) & (80.53) & $(0.00)$ & (100.00) \\
\hline \multirow[t]{2}{*}{2010} & 22 & 51 & 0 & 73 & 24 & 97 & 0 & 121 \\
\hline & (30.14) & (69.86) & $(0.00)$ & (100.00) & (19.83) & (80.17) & $(0.00)$ & (100.00) \\
\hline \multirow[t]{2}{*}{2011} & 11 & 29 & 1 & 41 & 61 & 115 & 5 & 181 \\
\hline & (26.83) & (70.73) & $(2.44)$ & (100.00) & (33.70) & (63.54) & (2.76) & $(100.00)$ \\
\hline \multirow[t]{2}{*}{2012} & 32 & 50 & 17 & 99 & 184 & 194 & 43 & 421 \\
\hline & (32.32) & $(50.51)$ & (17.17) & (100.00) & (43.71) & (46.08) & (10.21) & (100.00) \\
\hline \multirow[t]{2}{*}{2013} & 83 & 90 & 22 & 195 & 199 & 211 & 102 & 512 \\
\hline & $(42.56)$ & (46.15) & (11.28) & (100.00) & (38.87) & $(41.21)$ & (19.92) & $(100.00)$ \\
\hline \multirow[t]{2}{*}{2014} & 67 & 46 & 23 & 136 & 216 & 279 & 137 & 632 \\
\hline & (49.26) & $(33.82)$ & (16.91) & (100.00) & (34.18) & (44.15) & (21.68) & $(100.00)$ \\
\hline \multirow[t]{2}{*}{2015} & 137 & 131 & 88 & 356 & 83 & 148 & 52 & 283 \\
\hline & (38.48) & $(36.80)$ & $(24.72)$ & (100.00) & (29.33) & $(52.30)$ & (18.37) & $(100.00)$ \\
\hline
\end{tabular}




\begin{tabular}{lllllllll} 
total & 363 & 485 & 151 & 999 & 797 & 1250 & 339 & 2386 \\
& $(36.34)$ & $(48.55)$ & $(15.12)$ & $(100.00)$ & $(33.40)$ & $(52.39)$ & $(14.21)$ & $(100.00)$ \\
\hline
\end{tabular}

The distribution of Table ii reports the sample composition according to the professional background of the municipal party committee secretary and the number of companies with changes in the same industry in the same year. Obviously, the replacement of the municipal party committee secretary with a professional background in economic management accounted for a small proportion of the total sample, which was about $29 \%$. Looking at the annual situation, the number of people with a background in economics and management from the Secretary of the Municipal Party Committee has increased year by year, indicating that the four criteria for selecting cadres can help government officials to strengthen their professional knowledge in economics and management.

Table 2 Sample distribution (year-secretary professional background-number of companies with investment changes)

\begin{tabular}{|c|c|c|c|c|c|}
\hline \multirow{2}{*}{$\begin{array}{l}\text { Group } \\
\text { year }\end{array}$} & \multicolumn{2}{|c|}{$\begin{array}{l}\quad \text { Secretary of the } \\
\text { Municipal } \\
\text { Committee }\end{array}$} & \multicolumn{2}{|c|}{ Investment changes } & \multirow{2}{*}{ total } \\
\hline & $\begin{array}{l}\text { Non- } \\
\text { managem } \\
\text { ent }\end{array}$ & $\begin{array}{l}\text { Manage } \\
\text { ment }\end{array}$ & increase & decrease & \\
\hline 2007 & $\begin{array}{l}92 \\
(100.00)\end{array}$ & $\begin{array}{l}0 \\
(0.00)\end{array}$ & $\begin{array}{l}10 \\
(10.87)\end{array}$ & $\begin{array}{l}82 \\
(89.13)\end{array}$ & $\begin{array}{l}92 \\
(100.00)\end{array}$ \\
\hline 2008 & $\begin{array}{l}52 \\
(44.44)\end{array}$ & $\begin{array}{l}65 \\
(55.56)\end{array}$ & $\begin{array}{l}49 \\
(41.88)\end{array}$ & $\begin{array}{l}68 \\
(58.12)\end{array}$ & $\begin{array}{l}117 \\
(100.00)\end{array}$ \\
\hline 2009 & $\begin{array}{l}40 \\
(31.75)\end{array}$ & $\begin{array}{l}86 \\
(68.25)\end{array}$ & $\begin{array}{l}110 \\
(87.30)\end{array}$ & $\begin{array}{l}16 \\
(12.70)\end{array}$ & $\begin{array}{l}126 \\
(100.00)\end{array}$ \\
\hline 2010 & $\begin{array}{l}78 \\
(40.21)\end{array}$ & $\begin{array}{l}116 \\
(59.79)\end{array}$ & $\begin{array}{l}35 \\
(18.04)\end{array}$ & $\begin{array}{l}159 \\
(81.96)\end{array}$ & $\begin{array}{l}194 \\
(100.00)\end{array}$ \\
\hline 2011 & $\begin{array}{l}104 \\
(46.85)\end{array}$ & $\begin{array}{l}118 \\
(53.15)\end{array}$ & $\begin{array}{l}58 \\
(26.13)\end{array}$ & $\begin{array}{l}164 \\
(73.87)\end{array}$ & $\begin{array}{l}222 \\
(100.00)\end{array}$ \\
\hline 2012 & $\begin{array}{l}229 \\
(44.04)\end{array}$ & $\begin{array}{l}291 \\
(55.96)\end{array}$ & $\begin{array}{l}345 \\
(66.35)\end{array}$ & $\begin{array}{l}175 \\
(33.65)\end{array}$ & $\begin{array}{l}520 \\
(100.00)\end{array}$ \\
\hline 2013 & $\begin{array}{l}309 \\
(43.71)\end{array}$ & $\begin{array}{l}398 \\
(56.29)\end{array}$ & $\begin{array}{l}445 \\
(62.94)\end{array}$ & $\begin{array}{l}262 \\
(37.06)\end{array}$ & $\begin{array}{l}707 \\
(100.00)\end{array}$ \\
\hline 2014 & $\begin{array}{l}294 \\
(38.28)\end{array}$ & $\begin{array}{l}474 \\
(61.72)\end{array}$ & $\begin{array}{l}439 \\
(57.16)\end{array}$ & $\begin{array}{l}329 \\
(42.84)\end{array}$ & $\begin{array}{l}768 \\
(100.00)\end{array}$ \\
\hline 2015 & $\begin{array}{l}271 \\
(42.41)\end{array}$ & $\begin{array}{l}368 \\
(57.59)\end{array}$ & $\begin{array}{l}410 \\
(64.16)\end{array}$ & $\begin{array}{l}229 \\
(35.84)\end{array}$ & $\begin{array}{l}639 \\
(100.00)\end{array}$ \\
\hline Total & $\begin{array}{l}1469 \\
(43.40)\end{array}$ & $\begin{array}{l}1916 \\
(56.60)\end{array}$ & $\begin{array}{l}1901 \\
(56.16)\end{array}$ & $\begin{array}{l}1484 \\
(43.84)\end{array}$ & $\begin{array}{l}3385 \\
(100.00)\end{array}$ \\
\hline
\end{tabular}

\subsection{Models and variables}

(1) Model To test the impact of official turnover on investment synergy, the following OLS benchmark regression model was established: $C O M O V=\alpha+\beta_{1} C H A N G E+C O N T R O L s+I N D+Y E A R+\varepsilon \quad$ (1)

Among them, COMOV represents the synergy of investment, CHANGE represents the replacement of officials; and, CONTROLs, IND and YEAR respectively, control variables, industry effects and year effects, $\alpha$ is intercept term, and $\varepsilon$ represents model residual. Based on Hypothesis 1, we expect: $\beta_{1}>0$. In order to test the professional background of the secretary of the municipal party committee on the regulation of official turnover and investment synergy, this article established the following OLS regression model:

$C O M O V=\alpha+\beta_{1} C H A N G E+\beta_{2} M A J O R \times C H A N G E+C O N T R O L s+I N D+Y E A R+\varepsilon \quad$ (2) Among them, COMOV represents the synergy of investment, CHANGE represents the replacement of officials; and, CONTROLs, IND and $Y E A R$ respectively, control variables, industry effects and year effects, $\alpha$ is intercept term, and $\varepsilon$ represents model residual. Under Hypothesis 2, we expect: $\beta_{2}<0$.

(2) Variable definition (1)Investment synchronization measure 
Investment synchronization variable indicators are constructed separately from the industry and company levels according to the company's region. According to the research of Knyazeva et al. (2008), the ratio of the number of companies with increased investment and the number of companies with reduced investment in the region to the total number of companies in the same year and industry in the same year and industry is examined to establish investment synchronization The higher the index, the higher the synchronicity of investment decisions between companies in the same industry in the region. The company's investment is estimated using the cash flow statement method (ICF). Cash paid for fixed assets, intangible assets and other long-term assets in period t) / total assets at the beginning of period t.

$$
\operatorname{COMOV}(I)=\operatorname{Max}(\text { Nincrease }, \text { Ndecrease }) / N
$$

\section{(2) Change of Secretary of the Municipal Party Committee}

This article refers to the design of Wang Xianbin et al. (2009). If a newly appointed official takes office before June of that year, the year will be defined as the year of change in the city; if a newly appointed official takes office after June, it will be defined as the city change of the next year year. The data of the Secretary of the Municipal Party Committee was mainly from the Select City website. The missing data was manually collected through websites such as Baidu. (3) Control Variable The definitions of the control variables are shown in Table 3

Table 3 Variable definitions

\begin{tabular}{|c|c|c|c|}
\hline $\begin{array}{l}\text { Variable } \\
\text { type }\end{array}$ & Variable name & $\begin{array}{l}\text { Variable } \\
\text { code }\end{array}$ & Variable value method and description \\
\hline \multirow[t]{2}{*}{$\begin{array}{l}\text { Explained } \\
\text { variable }\end{array}$} & Investment synergy & COMOV & $\begin{array}{l}\text { See Zhang Dunli et al. (2015), Fang Junxiong (2012) and Chen Deqiu et } \\
\text { al. (2011) }\end{array}$ \\
\hline & Investment change & ISIGN & $\begin{array}{l}=1 \text {, the number of companies with increased investment in the region is } \\
\text { greater than the number of companies with reduced investment; = } 0 \text {, } \\
\text { others }\end{array}$ \\
\hline $\begin{array}{l}\text { Explanatory } \\
\text { variables }\end{array}$ & $\begin{array}{l}\text { City Party Secretary } \\
\text { changed }\end{array}$ & CHANGE & $\begin{array}{l}\text { Amount of government R \& D subsidy / total assets of the current period } \\
* 100\end{array}$ \\
\hline \multirow[t]{22}{*}{$\begin{array}{l}\text { Control } \\
\text { variable }\end{array}$} & $\begin{array}{l}\text { Professional } \\
\text { backgroundof secretary }\end{array}$ & MAJOR & $\begin{array}{l}=1 \text {, the secretary of the municipal Party committee has a professional } \\
\text { background in economics and management } ;=0 \text {, others }\end{array}$ \\
\hline & Secretary sex & GENDER & $=1$, woman; $=0$, man \\
\hline & Source of Secretary & FROM & $=1$, Off-site; $=0$, native \\
\hline & $\begin{array}{l}\text { Where the former } \\
\text { secretary went }\end{array}$ & L.TO & $=1$, Non-promotion; $=0$, promotion \\
\hline & Property right & STATE & $=1$, State-owned enterprise; $=0$, else \\
\hline & Industry concentration & HHI & $\begin{array}{l}\text { Herfindahl-Hirschman Index, the sum of squared income of main } \\
\text { business income of enterprises in the same industry in the same year }\end{array}$ \\
\hline & Analyst Tracks & COVER & Number of analysts tracked by listed companies that year \\
\hline & Company Size & SIZE & Natural logarithm of total assets at the end of the period \\
\hline & Assets and liabilities & LEV & Responsible Total at End of Period / Total Assets at End of Period \\
\hline & Current ratio & LIQUITY & $\begin{array}{l}\text { Total current assets at the end of the period / Total current liabilities at the } \\
\text { end of the period }\end{array}$ \\
\hline & Board size & BOARD & Total number of boards \\
\hline & $\begin{array}{l}\text { Proportion of } \\
\text { independent directors }\end{array}$ & INDB & Proportion of independent directors to the board \\
\hline & $\begin{array}{l}\text { Institutional } \\
\text { shareholding ratio }\end{array}$ & INS & Institutional investor shareholding \\
\hline & Equity concentration & TOP3 & Shareholdings of the top three shareholders \\
\hline & ROA & ROA & Net profit for the period / Total assets at the end of the period \\
\hline & MTB & MTB & $\begin{array}{l}\text { (End market value of equity + book value of liabilities) / end book value } \\
\text { of total assets }\end{array}$ \\
\hline & Listing age & AGE & Number of years since the company went public \\
\hline & Marketability index & MARKET & Marketization index of provinces and cities in the region \\
\hline & economic cycle & CYCL & $=1$, economic decline period $;=0$, other \\
\hline & Macroeconomic & GDPG & Growth rate of GDP of provinces and cities in the region \\
\hline & Industry & IND & Industry dummy variables \\
\hline & Year & YEAR & Annual dummy variable \\
\hline
\end{tabular}




\section{Analysis of empirical results}

\subsection{Descriptive statistics and univariate analysis}

Table 4 shows the descriptive statistics of the variables. It can be seen that the average value of corporate investment synergy is 0.62, and the median is about 0.60, which is not much different from Zhang Dunli et al. (2015) and Fang Junxiong (2012). About $21 \%$ of the sample companies in the region of the company were replaced by city party secretary that year About 29\% of the Municipal Party Secretary's records have a professional background in economic management. The values of other control variables are consistent with the current mainstream literature. In Table 5, we performed independent sample mean $\mathrm{T}$ test and median rank sum test for the official replacement group and the nonreplaced group. The univariate analysis results show that the mean and median of the investment synergy variables of listed companies are in the two groups. There are significant differences between them. The average and median values of the investment synergy variables of the sample of the Party committee secretary replacement group are significantly higher than those of the city committee secretary non-replacement group, which preliminarily proves the positive correlation between the secretary of the Party committee and the investment synergy of the enterprise.

Table 4 Descriptive statistics

\begin{tabular}{lllllll}
\hline variable & observations & mix & mean & median & max & $\begin{array}{l}\text { Standard } \\
\text { deviation }\end{array}$ \\
\hline COMOV & $3,385.000$ & 0.500 & 0.630 & 0.600 & 1.000 & 0.100 \\
ISIGN & $3,385.000$ & 0.000 & 0.440 & 0.000 & 1.000 & 0.500 \\
CHANGE & $3,385.000$ & 0.000 & 0.300 & 0.000 & 1.000 & 0.460 \\
MAJOR & $3,385.000$ & 0.000 & 0.570 & 1.000 & 1.000 & 0.500 \\
GENDER & $3,385.000$ & 0.000 & 0.040 & 0.000 & 1.000 & 0.200 \\
FROM & $3,385.000$ & 0.000 & 0.360 & 0.000 & 1.000 & 0.480 \\
TO & $3,385.000$ & 0.000 & 0.130 & 0.000 & 1.000 & 0.340 \\
STATE & $3,385.000$ & 0.000 & 0.130 & 0.000 & 1.000 & 0.340 \\
HHI & $3,385.000$ & 0.010 & 0.050 & 0.020 & 0.500 & 0.090 \\
COVER & $3,385.000$ & 0.000 & 5.750 & 3.000 & 47.000 & 6.840 \\
SIZE & $3,385.000$ & 10.050 & 12.730 & 12.590 & 16.540 & 1.210 \\
LEV & $3,385.000$ & 5.550 & 44.360 & 45.090 & 90.420 & 20.510 \\
LIQUITY & $3,385.000$ & 24.980 & 241.780 & 161.320 & $1,374.630$ & 238.110 \\
INS & $3,385.000$ & 0.000 & 38.520 & 39.820 & 87.420 & 23.860 \\
TOP3 & $3,385.000$ & 15.150 & 48.790 & 48.680 & 85.470 & 14.860 \\
ROA & $3,385.000$ & -15.670 & 5.570 & 5.150 & 27.020 & 5.570 \\
MTB & $3,385.000$ & 0.200 & 2.300 & 1.710 & 11.950 & 2.080 \\
DUAL & $3,385.000$ & 0.000 & 0.270 & 0.000 & 1.000 & 0.440 \\
INDB & $3,385.000$ & 30.000 & 37.160 & 33.330 & 57.140 & 5.130 \\
BOARD & $3,385.000$ & 4.000 & 8.690 & 9.000 & 18.000 & 1.780 \\
AGE & $3,385.000$ & 2.000 & 9.240 & 7.000 & 25.000 & 6.210 \\
MARKET & $3,385.000$ & 5.120 & 10.210 & 10.420 & 11.800 & 1.490 \\
CYCL & $3,385.000$ & 0.000 & 0.290 & 0.000 & 1.000 & 0.460 \\
GDPG & $3,385.000$ & 6.900 & 8.050 & 7.650 & 14.200 & 1.440 \\
\hline
\end{tabular}

Note: $* * *, * *, *$ represent the significance levels of statistical tests at $1 \%, 5 \%$, and $10 \%$, respectively 
Table 5 Mean and median tests

\begin{tabular}{|c|c|c|c|c|c|}
\hline \multirow{2}{*}{ Panel A } & \multirow{2}{*}{\multicolumn{2}{|c|}{ Current secretary }} & & Secretary & \multirow[b]{3}{*}{$\begin{array}{l}\text { Mean } \\
\text { difference }\end{array}$} \\
\hline & & & \multicolumn{2}{|c|}{ Replacement Group } & \\
\hline Mean t test & \multirow{4}{*}{$\begin{array}{l}\text { Observati } \\
\text { ons } \\
2386 \\
\text { Observati } \\
\text { ons } \\
2386\end{array}$} & Mean & \multirow{4}{*}{$\begin{array}{l}\text { Observati } \\
\text { ons } \\
999 \\
\text { Observati } \\
\text { ons } \\
999\end{array}$} & Mean & \\
\hline COMOV & & 0.625 & & 0.635 & $-0.011^{* * *}$ \\
\hline $\begin{array}{ll}\text { Median rank } \\
\text { sum test }\end{array}$ & & Median & & Median & Bangla \\
\hline COMOV & & 0.600 & & 0.600 & 0.955 \\
\hline Panel B & \multicolumn{2}{|c|}{$\begin{array}{l}\text { The lag } 1 \text { secretary has } \\
\text { not been replaced }\end{array}$} & \multicolumn{2}{|c|}{$\begin{array}{l}\text { Lag Phase } 1 \text { Secretary } \\
\text { Replacement Group }\end{array}$} & \\
\hline Mean $t$ test & $\begin{array}{l}\text { Observati } \\
\text { ons }\end{array}$ & Mean & $\begin{array}{l}\text { Observati } \\
\text { ons }\end{array}$ & Mean & $\begin{array}{l}\text { Mean } \\
\text { difference }\end{array}$ \\
\hline COMOV & 2303 & 0.624 & 592 & 0.643 & $-0.019^{* * * *}$ \\
\hline $\begin{array}{l}\text { Median rank } \\
\text { sum test }\end{array}$ & $\begin{array}{l}\text { Observati } \\
\text { ons }\end{array}$ & Median & $\begin{array}{l}\text { Observati } \\
\text { ons }\end{array}$ & Median & Bangla \\
\hline COMOV & 2303 & 0.586 & 592 & 0.621 & $56.831^{* * *}$ \\
\hline
\end{tabular}

\subsection{Multiple linear regression}

(1) Official turnover and investment synergy

First of all, this paper tests the impact of official turnover on corporate investment synergy. The results are shown in column (1) of table 6. In the current period of official turnover, investment synergy is significantly positive at the level of $1 \%$, which indicates that official turnover can improve the synergy of corporate investment behavior. Hypothesis 1a is verified. We continue to divide the whole sample into investment increase group and investment decrease group to investigate how the change of municipal Party Secretary affects the herding effect of investment. In the investment reduction group, the results are shown in column (2) of table 6 , and we found that the results are consistent with the test results of the whole sample. However, in the investment increase group, the results are shown in column (3) of table 6. The synergy effect of the increase in the number of investment caused by the replacement of municipal Party committee secretaries is significantly negative, which shows that the main reason for the herd effect of investment in the whole sample is that the environmental uncertainty caused by the replacement of municipal Party committee secretaries makes the investment level of enterprises generally decline. According to the classification of property rights, the results are shown in columns (4) and (5) of table 6. The investment synergy of state-owned enterprises is significantly positive at the level of $5 \%$, while that of non-state-owned enterprises is significantly positive at the level of $1 \%$. This shows that when the municipal Party committee Secretary changes, the herding effect of non-state-owned enterprises' investment is more obvious, that is, the attitude of non-state-owned enterprises to risk is more secure Guard and be cautious. The reasons are as follows: on the one hand, state-owned enterprises are closely related to the government, and the news of official turnover is easy to be known by state-owned enterprises in advance, so that the operational risk of state-owned enterprises is small, while the impact on non-state-owned enterprises is large; on the other hand, state-owned enterprises have always been bearing the policy burden of the government, and their main task is to complete the tasks assigned by the government The impact of investment guidance is relatively small, while nonstate-owned enterprises generally identify investment opportunities based on external signals, so the impact of official turnover on non-state-owned enterprises is relatively large. 
Table 6 Regression Analysis of the coordination between official turnover and investment

\begin{tabular}{|c|c|c|c|c|c|}
\hline & $\begin{array}{l}\text { Full sample } \\
\text { (1) }\end{array}$ & $\begin{array}{l}\text { Reduced } \\
\text { investment } \\
\text { (2) }\end{array}$ & $\begin{array}{l}\text { Increased } \\
\text { investment } \\
\text { (3) }\end{array}$ & $\begin{array}{l}\text { State-owned } \\
\text { (4) }\end{array}$ & $\begin{array}{l}\text { Non-state } \\
\text { (5) }\end{array}$ \\
\hline CHANGE & $\begin{array}{l}0.023 * * * \\
(5.58)\end{array}$ & $\begin{array}{l}0.047 * * * \\
(8.07)\end{array}$ & $\begin{array}{l}-0.016 * * * \\
(-2.68)\end{array}$ & $\begin{array}{l}0.028 * * \\
(2.38)\end{array}$ & $\begin{array}{l}0.023 * * * \\
(5.05)\end{array}$ \\
\hline GDPG & $\begin{array}{l}0.011 * * * \\
(7.71)\end{array}$ & $\begin{array}{l}0.029 * * * \\
(19.43)\end{array}$ & $\begin{array}{l}0.011 * * * \\
(6.64)\end{array}$ & $\begin{array}{l}0.015^{* * * *} \\
(5.58)\end{array}$ & $\begin{array}{l}0.009 * * * \\
(4.16)\end{array}$ \\
\hline MAJOR & $\begin{array}{l}-0.017 * * * \\
(-5.20)\end{array}$ & $\begin{array}{l}-0.018 * * * \\
(-4.12)\end{array}$ & $\begin{array}{l}-0.009^{*} \\
(-1.77)\end{array}$ & $\begin{array}{l}-0.007 \\
(-0.64)\end{array}$ & $\begin{array}{l}-0.019 * * * \\
(-5.46)\end{array}$ \\
\hline MARKET & $\begin{array}{l}-0.015^{* * *} \\
(-10.80)\end{array}$ & $\begin{array}{l}-0.017 * * * \\
(-9.69)\end{array}$ & $\begin{array}{l}-0.008 * * * \\
(-4.46)\end{array}$ & $\begin{array}{l}-0.019 * * * \\
(-4.93)\end{array}$ & $\begin{array}{l}-0.014 * * * \\
(-9.46)\end{array}$ \\
\hline STATE & $\begin{array}{l}0.013 * * \\
(2.27)\end{array}$ & $\begin{array}{l}0.006 \\
(0.81)\end{array}$ & $\begin{array}{l}0.022 * * * \\
(2.84)\end{array}$ & & \\
\hline HHI & $\begin{array}{l}0.190 * * * \\
(3.95)\end{array}$ & $\begin{array}{l}0.109 * * * \\
(2.91)\end{array}$ & $\begin{array}{l}0.196 \text { *** } \\
(3.37)\end{array}$ & $\begin{array}{l}-0.104 \\
(-0.75)\end{array}$ & $\begin{array}{l}0.238^{* * * *} \\
(4.64)\end{array}$ \\
\hline COVER & $\begin{array}{l}0.000 \\
(0.12)\end{array}$ & $\begin{array}{l}0.000 \\
(0.45)\end{array}$ & $\begin{array}{l}-0.000 \\
(-0.27)\end{array}$ & $\begin{array}{l}-0.001 \\
(-0.91)\end{array}$ & $\begin{array}{l}0.000 \\
(0.26)\end{array}$ \\
\hline SIZE & $\begin{array}{l}-0.003 \\
(-1.27)\end{array}$ & $\begin{array}{l}-0.003 \\
(-1.05)\end{array}$ & $\begin{array}{l}0.000 \\
(0.15)\end{array}$ & $\begin{array}{l}-0.003 \\
(-0.44)\end{array}$ & $\begin{array}{l}-0.002 \\
(-1.05)\end{array}$ \\
\hline LEV & $\begin{array}{l}0.000^{* *} \\
(2.16)\end{array}$ & $\begin{array}{l}0.000 \\
(1.03)\end{array}$ & $\begin{array}{l}0.000 \\
(1.62)\end{array}$ & $\begin{array}{l}-0.000 \\
(-0.18)\end{array}$ & $\begin{array}{l}0.000^{* *} \\
(2.25)\end{array}$ \\
\hline LIQUITY & $\begin{array}{l}0.000 \\
(0.65)\end{array}$ & $\begin{array}{l}-0.000 \\
(-0.22)\end{array}$ & $\begin{array}{l}0.000 \\
(0.85)\end{array}$ & $\begin{array}{l}-0.000 \\
(-1.15)\end{array}$ & $\begin{array}{l}0.000 \\
(1.01)\end{array}$ \\
\hline BOARD & $\begin{array}{l}0.000 \\
(0.35)\end{array}$ & $\begin{array}{l}0.001 \\
(0.39)\end{array}$ & $\begin{array}{l}-0.001 \\
(-0.53)\end{array}$ & $\begin{array}{l}0.000 \\
(0.08)\end{array}$ & $\begin{array}{l}0.000 \\
(0.29)\end{array}$ \\
\hline INDB & $\begin{array}{l}-0.001 * * \\
(-2.40)\end{array}$ & $\begin{array}{l}-0.001 * * \\
(-2.26)\end{array}$ & $\begin{array}{l}-0.001 \\
(-1.62)\end{array}$ & $\begin{array}{l}-0.001 \\
(-0.76)\end{array}$ & $\begin{array}{l}-0.001 * * \\
(-2.19)\end{array}$ \\
\hline INS & $\begin{array}{l}0.000 \\
(0.12)\end{array}$ & $\begin{array}{l}0.000 \\
(0.14)\end{array}$ & $\begin{array}{l}0.000 \\
(0.40)\end{array}$ & $\begin{array}{l}0.000 \\
(1.15)\end{array}$ & $\begin{array}{l}0.000 \\
(0.06)\end{array}$ \\
\hline TOP3 & $\begin{array}{l}0.000 \\
(0.00)\end{array}$ & $\begin{array}{l}0.000 \\
(0.18)\end{array}$ & $\begin{array}{l}-0.000 \\
(-0.78)\end{array}$ & $\begin{array}{l}-0.000 \\
(-0.58)\end{array}$ & $\begin{array}{l}-0.000 \\
(-0.23)\end{array}$ \\
\hline ROA & $\begin{array}{l}0.000 \\
(0.16)\end{array}$ & $\begin{array}{l}-0.000 \\
(-0.14)\end{array}$ & $\begin{array}{l}-0.000 \\
(-0.33)\end{array}$ & $\begin{array}{l}0.002 \\
(1.32)\end{array}$ & $\begin{array}{l}-0.000 \\
(-0.40)\end{array}$ \\
\hline MTB & $\begin{array}{l}-0.001 \\
(-1.32)\end{array}$ & $\begin{array}{l}-0.001 \\
(-0.86)\end{array}$ & $\begin{array}{l}-0.000 \\
(-0.15)\end{array}$ & $\begin{array}{l}-0.002 \\
(-0.43)\end{array}$ & $\begin{array}{l}-0.001 \\
(-1.09)\end{array}$ \\
\hline AGE & $\begin{array}{l}0.000 \\
(0.26)\end{array}$ & $\begin{array}{l}0.000 \\
(0.06)\end{array}$ & $\begin{array}{l}0.000 \\
(0.92)\end{array}$ & $\begin{array}{l}0.001 \\
(0.73)\end{array}$ & $\begin{array}{l}-0.000 \\
(-0.06)\end{array}$ \\
\hline Industry & Control & Control & Control & control & Control \\
\hline Year & Control & Control & Control & Control & Control \\
\hline Constant & $\begin{array}{l}0.718 * * * \\
(18.49)\end{array}$ & $\begin{array}{l}0.778 * * * \\
(14.77)\end{array}$ & $\begin{array}{l}0.657 * * * \\
(12.23)\end{array}$ & $\begin{array}{l}0.861 * * * \\
(7.75)\end{array}$ & $\begin{array}{l}0.713 * * * \\
(16.63)\end{array}$ \\
\hline Observations & 3,385 & 1,901 & 1,484 & 447 & 2,938 \\
\hline R2_adjust & 0.261 & 0.284 & 0.389 & 0.289 & 0.242 \\
\hline
\end{tabular}

Note: $* * *, * *, *$ respectively represent statistical test significance level of $1 \%, 5 \%, 10 \%$. Note: $* * *, * *, *$ respectively represent statistical test significance level of $1 \%, 5 \%, 10 \%$.

(2) The regulating role of macro environment and official characteristics

We further investigate whether the macro environment and the characteristics of officials can affect the relationship between the change of officials and the investment synergy of enterprises. In terms of macro environment, $C H A N G E \times C Y C L, C H A N G E \times M A R K E T$ and $C H A N G E \times G D P G$ are introduced as the level of marketization, the level of economic development and the economic cycle as the interactive items of the replacement of the municipal Party secretary. The regression results are shown in columns (1), (2) and (3) of table 7. It can be seen from columns (1) and 
(2) that the results of interaction terms $C H A N G E \times M A R K E T$ and $C H A N G E \times G D P G$ are significantly negative, which shows that in areas with high level of marketization and economic development, the change of municipal party secretary has limited impact on herding caused by environmental uncertainty, thus proving hypothesis $2 \mathrm{a}$ and hypothesis $2 \mathrm{~B}$. It can be seen from column (3) that the result of the interaction term is significantly positive, which shows that in economic depression, the turbulence of political environment will enhance the herding effect of investment decline, which verifies hypothesis 2C. In the aspect of official characteristics, they are introduced $C H A N G E \times F R O M C H A N G E \times M A J O R$ and CHANGE $\times L . T O$ as professional background, derived from the interaction items of whereabouts and the replacement of municipal Party secretary. The regression results are shown in columns (4), (5) and (6) of table 7. In column (4), the coefficient of interaction between official turnover and professional background $C H A N G E \times M A J O R$ is significantly negative at the level of $1 \%$. The regression results show that in the year of official turnover, the new municipal Party secretary with professional background in economic management is more inclined to use the way of market law to conduct micro enterprise investment behavior Intervention, which leads to the decrease of the synergy of enterprise investment, can prove hypothesis $3 a$.

We further find that succession officials from different places will reduce the investment synergy of enterprises. The results are shown in column (5) of table 7 . The coefficient $C H A N G E \times F R O M$ is significantly negative, which indicates that enterprises will collect more information to reduce investment synergy after unfamiliar officials take office, which verifies hypothesis 3B. Finally, we find that in column (6), the multiplier CHANGE $\times$ L.TO is significantly positive, which indicates that the departure of officials in an abnormal way will lead to the increase of the uncertainty of the political environment, thus enhancing the herding effect of enterprises' investment, thus proving the hypothesis $3 \mathrm{C}$.

Table 7 Regression analysis of moderating effects of macro environment and official characteristics

\begin{tabular}{|c|c|c|c|c|c|c|}
\hline \multirow{2}{*}{ variable } & \multicolumn{2}{|c|}{ Macro environment } & \multicolumn{4}{|c|}{ Official characteristics } \\
\hline & (1) & (2) & (3) & (4) & $(5)$ & (6) \\
\hline CHANGE & $0.170^{* * * *}$ & $0.092^{* * * * 4}$ & $0.014^{* * * *}$ & $0.040^{* * * *}$ & $0.040^{\text {****** }}$ & $0.021^{\text {**** }}$ \\
\hline & $(4.70)$ & $(4.15)$ & $(2.93)$ & $(6.93)$ & $(6.56)$ & $(4.72)$ \\
\hline FROM & & & & & $0.019^{* * *}$ & 0.006 \\
\hline & & & & & $(4.14)$ & $(1.53)$ \\
\hline L.TO & & & & & 0.000 & -0.009 \\
\hline & & & & & $(0.04)$ & $(-1.36)$ \\
\hline GDPG & $0.010^{* * *}$ & $0.016^{* * *}$ & $0.044^{* * *}$ & $0.009^{* * * *}$ & $0.063^{* * *}$ & $0.057^{* * *}$ \\
\hline & $(6.84)$ & $(6.47)$ & $(4.36)$ & $(6.79)$ & $(5.84)$ & $(5.44)$ \\
\hline MAJOR & $-0.016^{* * *}$ & $-0.018^{* * * *}$ & $-0.017^{* * *}$ & $-0.007 *$ & $-0.014^{* * *}$ & $-0.017^{* * *}$ \\
\hline & $(-4.93)$ & $(-5.26)$ & $(-5.15)$ & $(-1.91)$ & $(-3.93)$ & $(-4.66)$ \\
\hline MARKET & $-0.011^{* * * *}$ & $-0.015^{* * *}$ & $-0.015^{* * *}$ & $-0.014^{* * *}$ & $-0.015^{* * *}$ & $-0.015^{* * *}$ \\
\hline & $(-7.83)$ & $(-11.08)$ & $(-10.99)$ & $(-10.53)$ & $(-10.32)$ & $(-9.96)$ \\
\hline CYCL & & & $\begin{array}{l}-0.263^{\text {*****1}} \\
(-3.67)\end{array}$ & & & \\
\hline CHANGE*MAJOR & & & & $\begin{array}{l}-0.035^{* * * *} \\
(-4.95)\end{array}$ & & \\
\hline CHANGE*MARKE & $-0.014^{* * *}$ & & & & & \\
\hline & $(-4.18)$ & & & & & \\
\hline CHANGE*FROM & & & & & $\begin{array}{l}-0.039^{* * *} \\
(-4.47)\end{array}$ & \\
\hline CHANGE*L.TO & & & & & & $\begin{array}{l}0.043^{* *} \\
(2.28)\end{array}$ \\
\hline CHANGE*GDPG & & $\begin{array}{l}-0.008^{* * *} \\
(-3.06)\end{array}$ & & & & \\
\hline CHANGE*CYCL & & & $\begin{array}{l}0.027^{* * *} \\
(3.10)\end{array}$ & & & \\
\hline STATE & $\begin{array}{l}0.013^{* *} \\
(2.24)\end{array}$ & $\begin{array}{l}0.013^{* *} \\
(2.26)\end{array}$ & $\begin{array}{l}0.013^{* *} \\
(2.29)\end{array}$ & $\begin{array}{l}0.014^{* *} \\
(2.38)\end{array}$ & $\begin{array}{l}0.014^{* *} \\
(2.29)\end{array}$ & $\begin{array}{l}0.014^{* *} \\
(2.22)\end{array}$ \\
\hline HHI & $\begin{array}{l}0.193^{\text {**** }} \\
(3.97)\end{array}$ & $\begin{array}{l}0.201^{\text {**** }} \\
(4.08)\end{array}$ & $\begin{array}{l}0.193^{\text {**** }} \\
(4.10)\end{array}$ & $\begin{array}{l}0.177^{* * * *} \\
(3.66)\end{array}$ & $\begin{array}{l}0.233^{\text {**** }} \\
(4.09)\end{array}$ & $\begin{array}{l}0.213^{* * *} \\
(3.62)\end{array}$ \\
\hline
\end{tabular}




\begin{tabular}{lllllll} 
COVER & 0.000 & 0.000 & 0.000 & 0.000 & 0.000 & 0.000 \\
SIZE & $(0.19)$ & $(0.15)$ & $(0.18)$ & $(0.07)$ & $(1.14)$ & $(1.03)$ \\
& -0.003 & -0.003 & -0.003 & -0.003 & $-0.005^{* *}$ & $-0.004^{*}$ \\
LEV & $(-1.28)$ & $(-1.33)$ & $(-1.29)$ & $(-1.27)$ & $(-2.19)$ & $(-1.88)$ \\
& $0.000^{* *}$ & $0.000^{* *}$ & $0.000^{* *}$ & $0.000^{* *}$ & $0.000^{* *}$ & $0.000^{* *}$ \\
LIQUITY & $(2.16)$ & $(2.09)$ & $(2.27)$ & $(2.18)$ & $(2.13)$ & $(2.01)$ \\
& 0.000 & 0.000 & 0.000 & 0.000 & 0.000 & 0.000 \\
BOARD & $(0.62)$ & $(0.61)$ & $(0.71)$ & $(0.57)$ & $(0.82)$ & $(0.67)$ \\
& 0.000 & 0.000 & 0.000 & 0.000 & 0.000 & 0.001 \\
INDB & $(0.20)$ & $(0.42)$ & $(0.21)$ & $(0.31)$ & $(0.40)$ & $(0.43)$ \\
& $-0.001^{* * *}$ & $-0.001^{* *}$ & $-0.001^{* *}$ & $-0.001^{* *}$ & $-0.001^{* *}$ & $-0.001^{* *}$ \\
INS & $(-2.65)$ & $(-2.41)$ & $(-2.45)$ & $(-2.31)$ & $(-2.25)$ & $(-2.27)$ \\
& 0.000 & -0.000 & 0.000 & 0.000 & 0.000 & 0.000 \\
TOP3 & $(0.12)$ & $(-0.04)$ & $(0.22)$ & $(0.19)$ & $(0.85)$ & $(0.73)$ \\
& -0.000 & 0.000 & -0.000 & -0.000 & -0.000 & -0.000 \\
ROA & $(-0.03)$ & $(0.20)$ & $(-0.07)$ & $(-0.01)$ & $(-0.48)$ & $(-0.49)$ \\
& 0.000 & 0.000 & 0.000 & 0.000 & -0.000 & -0.000 \\
MTB & $(0.13)$ & $(0.20)$ & $(0.12)$ & $(0.13)$ & $(-0.26)$ & $(-0.16)$ \\
& -0.001 & -0.001 & -0.001 & -0.001 & -0.001 & -0.001 \\
AGE & $(-1.40)$ & $(-1.30)$ & $(-1.37)$ & $(-1.25)$ & $(-1.42)$ & $(-1.08)$ \\
& 0.000 & 0.000 & 0.000 & 0.000 & -0.000 & -0.000 \\
Constant & $(0.20)$ & $(0.45)$ & $(0.04)$ & $(0.25)$ & $(-0.49)$ & $(-0.52)$ \\
Industry & $0.639^{* * *}$ & $0.624^{* * *}$ & $0.440^{* * *}$ & $0.663^{* * *}$ & $0.320^{* * *}$ & $0.369^{* * *}$ \\
Year & $(16.06)$ & $(14.86)$ & $(5.26)$ & $(16.74)$ & $(3.60)$ & $(4.29)$ \\
\hline Observations & control & control & Control & Control & control & Control \\
R2_adjust & control & Control & control & Control & Control & control \\
\hline
\end{tabular}

Note: $* * *, * *, *$ represent the significance level of statistical test is $1 \%, 5 \%, 10 \%$ respectively。

\section{Robustness test}

In order to ensure the reliability of the research results, we tried to carry out a variety of robustness tests. The main three aspects are sample elimination, variable replacement and selection bias. In order to eliminate the impact of the international financial crisis in 2008, we only keep the sample records after 2009 (inclusive). See Table 8, column (1), for the regression results of all variables, which are in good agreement with the benchmark regression model. In addition, we use the balance sheet method to measure the investment synergy of enterprises according to the practices of Fang Junxiong (2012) and Zhang Dunli (2015). The total investment of enterprises in phase $t=$ (the increase of fixed assets in phase $t+$ the increase of intangible assets in phase $t+$ the increase of construction in process in phase $t$ ) / the total assets at the beginning of phase T. The regression results are shown in column (2) of table 8. In addition, in order to ensure the investment synergy of the company For the scientificity of the same-sex test, we only keep the records of at least 5 companies in the same industry and region in the same year; therefore, there is a certain selection error in the samples. In order to eliminate the possible regression errors caused by such sample selection errors, we use Heckman's (1979) method for reference to build a two-stage regression model. In the first stage, we build a virtual variable (SII, = 1, if the sample records meet the requirements of at least 5 companies in the same industry and region in the same year; $=0$, others $)$ as the explained variables, and take the company size, asset liability ratio, and analysis The number of division pursuits, current ratio, board size, proportion of independent directors, institutional shareholding ratio, equity concentration, return on total assets, Tobin Q value, listing age, professional background of municipal Party committee secretary and regional GDP growth rate are explanatory variables. Probit selection regression model is established and inverse mills' ratio is calculated In the second stage, the IMR is put into the benchmark regression model to control the possible correlation of the residual items of the benchmark regression model and eliminate the endogenous problems caused by sample selection errors. See column (3) of table 8 for regression results after considering sample selection bias. In short, the empirical results of various tests maintain a good robustness, which shows that the conclusions of this paper are reliable. 
Table 8 Robustness test

\begin{tabular}{|c|c|c|c|}
\hline variable & $\begin{array}{l}\text { Eliminate the impact of the } \\
\text { financial crisis } \\
\text { (1) }\end{array}$ & $\begin{array}{l}\text { Variable substitution } \\
\text { (2) }\end{array}$ & $\begin{array}{l}\text { Selection bias } \\
\text { (3) }\end{array}$ \\
\hline CHANGE & $\begin{array}{l}0.025 * * * \\
(5.84)\end{array}$ & $\begin{array}{l}0.015^{* * *} \\
(3.04)\end{array}$ & $\begin{array}{l}0.017 * * * \\
(3.38)\end{array}$ \\
\hline GDPG & $\begin{array}{l}0.032 * * * \\
(9.36)\end{array}$ & $\begin{array}{l}0.002 \\
(0.97)\end{array}$ & $\begin{array}{l}-0.004 \\
(-1.32)\end{array}$ \\
\hline MAJOR & $\begin{array}{l}-0.019 * * * \\
(-5.73)\end{array}$ & $\begin{array}{l}-0.014 * * * \\
(-2.95)\end{array}$ & $\begin{array}{l}0.001 \\
(0.24)\end{array}$ \\
\hline MARKET & $\begin{array}{l}-0.014 * * * \\
(-10.19)\end{array}$ & $\begin{array}{l}-0.006^{* * * *} \\
(-3.75)\end{array}$ & $\begin{array}{l}-0.006^{* * *} \\
(-3.26)\end{array}$ \\
\hline STATE & $\begin{array}{l}0.010 \\
(1.62)\end{array}$ & $\begin{array}{l}0.010 \\
(1.57)\end{array}$ & $\begin{array}{l}0.002 \\
(0.22)\end{array}$ \\
\hline HHI & $\begin{array}{l}0.294 * * * \\
(5.68)\end{array}$ & $\begin{array}{l}0.104 * * \\
(2.28)\end{array}$ & $\begin{array}{l}0.026 \\
(0.49)\end{array}$ \\
\hline COVER & $\begin{array}{l}-0.000 \\
(-0.12)\end{array}$ & $\begin{array}{l}0.000 \\
(0.34)\end{array}$ & $\begin{array}{l}-0.000 \\
(-0.01)\end{array}$ \\
\hline SIZE & $\begin{array}{l}-0.002 \\
(-1.03)\end{array}$ & $\begin{array}{l}-0.002 \\
(-0.85)\end{array}$ & $\begin{array}{l}0.000 \\
(0.09)\end{array}$ \\
\hline LEV & $\begin{array}{l}0.000 * * \\
(2.54)\end{array}$ & $\begin{array}{l}-0.000 \\
(-0.37)\end{array}$ & $\begin{array}{l}-0.000 \\
(-0.69)\end{array}$ \\
\hline LIQUITY & $\begin{array}{l}0.000 \\
(0.89)\end{array}$ & $\begin{array}{l}-0.000^{* *} \\
(-2.45)\end{array}$ & $\begin{array}{l}-0.000 \\
(-1.34)\end{array}$ \\
\hline BOARD & $\begin{array}{l}0.000 \\
(0.25)\end{array}$ & $\begin{array}{l}0.003 * * \\
(2.09)\end{array}$ & $\begin{array}{l}0.004 * * * \\
(2.67)\end{array}$ \\
\hline INDB & $\begin{array}{l}-0.001 * * \\
(-2.39)\end{array}$ & $\begin{array}{l}-0.000 \\
(-0.98)\end{array}$ & $\begin{array}{l}-0.000 \\
(-0.56)\end{array}$ \\
\hline INS & $\begin{array}{l}0.000 \\
(0.07)\end{array}$ & $\begin{array}{l}-0.000 \\
(-0.93)\end{array}$ & $\begin{array}{l}-0.000 \\
(-0.96)\end{array}$ \\
\hline TOP3 & $\begin{array}{l}-0.000 \\
(-0.72)\end{array}$ & $\begin{array}{l}0.000 \\
(0.66)\end{array}$ & $\begin{array}{l}0.000 \\
(1.44)\end{array}$ \\
\hline ROA & $\begin{array}{l}0.000 \\
(0.44)\end{array}$ & $\begin{array}{l}0.001^{* *} \\
(2.00)\end{array}$ & $\begin{array}{l}0.001 * \\
(1.68)\end{array}$ \\
\hline МТВ & $\begin{array}{l}-0.001 \\
(-0.90)\end{array}$ & $\begin{array}{l}-0.003 * * * \\
(-2.78)\end{array}$ & $\begin{array}{l}-0.002 * \\
(-1.84)\end{array}$ \\
\hline AGE & $\begin{array}{l}-0.000 \\
(-0.40)\end{array}$ & $\begin{array}{l}-0.002 * * * \\
(-5.86)\end{array}$ & $\begin{array}{l}-0.003 * * * \\
(-6.07)\end{array}$ \\
\hline IMR & & & $\begin{array}{l}0.079^{* * *} \\
(3.29)\end{array}$ \\
\hline $\begin{array}{l}\text { Industry } \\
\text { Year }\end{array}$ & $\begin{array}{l}\text { control } \\
\text { control }\end{array}$ & $\begin{array}{l}\text { control } \\
\text { control }\end{array}$ & $\begin{array}{l}\text { control } \\
\text { control }\end{array}$ \\
\hline Constant & $\begin{array}{l}0.670 * * * \\
(13.80)\end{array}$ & $\begin{array}{l}0.673 * * * \\
(13.95)\end{array}$ & $\begin{array}{l}0.503 * * * \\
(8.05)\end{array}$ \\
\hline
\end{tabular}




$\begin{array}{llrl}\text { Observations } & 3,176 & 3,385 & 3,068\end{array}$

R2_adjust $\quad 0.276 \quad 0.140 \quad 0.145$

Note: $* * *, * *, *$ represent the significance levels of statistical tests at $1 \%, 5 \%$, and 10\%, respectively.

\section{Conclusion}

This paper selects all non-financial A-share listed companies from 2007 to 2015 as samples to investigate the impact of official turnover on corporate investment synergy. Generally speaking, this paper provides new evidence that the motivation of corporate investment synergy can be improved in the year of official turnover, but the effect is different in different macro environments and with different characteristics of officials. This paper supplements the empirical literature on the impact of official turnover on corporate behavior, and provides new evidence on the consequences of macro environment and personal characteristics of officials. This paper further finds that the main reason for the investment congruence is the manager's tendency to shirk responsibility caused by the uncertainty of political environment brought about by the replacement of officials, that is, the investors reflect not the imitation behavior based on the pursuit of interests, but the collective understanding of risks. This paper focuses on the role and conditions of government intervention in the investment decision-making of enterprises, which provides a theoretical basis for the investment decision-making of enterprises.

\section{References:}

Bikhchandani, S., and Sharma, S.: Herd Behavior in Financial Markets: A Review. IMF Working Paper, 2000.

Chordia, T., and Shivakumar, L.: Momentum, Business Cycle and Time-Varying Expected Returns.Journal of Finance, 2002, 57(2) : 985-1019.

Donghua, C., Saqib, K., Xin, Y. and Zhou, Z.: Government Intervention and Investment Comovement: Chinese Evidence. Journal of Business Finance \& Accounting, 2013,40 (3-4): 564-587.

Fan J. P. H., Wei, K.C.J., and Xu, X.: Corporate Finance and Governance in Emerging Markets: A Selective Review and An Agenda for Future Research. Journal of Corporate Finance, 2011, 17(2): 207-214.

Holmes, P., Kallinterakis, V., and Ferreira, M. P. L.: Herding in A Concentrated Market: A Question of Intent. European Financial Management, 2013,19(3): 497-520.

Hong, H., Kubik, J. D., and Stein, J. C.: The Neighbor's Portfolio: Word-of-Mouth Effects in the Holdings and Trades of Money Managers. Journal of Finance, 2005, 60(6): 2801-2824.

Hwang, S., and Salmon, M.: Market Stress and Herding. Journal of Empirical Finance. 2004,11(4): 585-616.

Julio, B., and Yook, Y.: Political Uncertainty and Corporate Investment Cycles. Journal of Finance, 67(1), 2012: 45-83.

Knyazeva, A., Knyazeva, D., Morck, R., and Yeung, B.: Comovement in Investment. University of Rochester Working Paper, 2008.

Morck, R., Yeung, B., and Yu, W.: The Information Content of Stock Markets: Why Do Emerging Markets Have Synchronous Stock Price Movements? Journal of Financial Economics, 2000, 58(1): 215-260.

Olson, K. R.: A Literature Review of Social Mood. Journal of Behavior Finance. 2006, 7 (4): 193-203.

Parker, W. D., and Prechter, R. R.: Herding: An Interdisciplinary Integrative Review from a Socionomic Perspective, Working Paper, 2005.

Prechter, R. R.: Unconscious Herding Behavior as the Psychological Basis of Financial Market Trends and Patterns. Journal of Psychology Finance Markets. 2001, 2 (3): 120-125.

Shu, H. C.: Investor Mood and Financial Markets. Journal of Economics Behavior and Organization, 2010, 76(2): 267282.

Siganos, A., Vagenas-Nanos, E., and Verwijmeren, P.: Facebook's Daily Sentiment and International Stock Markets. Journal of Economics Behavior and Organization. 2014, 107(B): 730-743.

Teh, L. L., DeBondt, and W. F. M.: Herding Behavior and Stock Returns: An Exploratory Investigation. Swiss Journal of Economics and Statistics, 1997, 133(2): 293-324.

Wermers, R.: Mutual Fund Herding and the Impact on Stock Prices. Journal of Finance. 1999, 54 (2): 581-622.

Wright, W. F., and Bower, G. H.: Mood Effects on Subjective Probability Assessment. Organizational Behavior and Human Decision Process, 1992, 52(2): 276-291.

Cao Chunfang: political power transfer and corporate investment: the logic of China, management world, 2013, issue 1.

Chen deqiu, Chen yunsen: government governance, ultimate property rights and synchronization of corporate investment, management review, 2013, issue 1.

Chen Yanyan and Luo Dang: local official turnover and enterprise investment, economic research, 2012, issue 2. 
Cheng Zhe, Bai Yunxia: financing impulse, capital allocation efficiency and frequency of local officials' turnover, reform, 2015, issue 8 .

Fang Junxiong: convergence of enterprise investment decision: herding effect or "tide phenomenon", financial research, No. 11, 2012.

Jiang Peng, Wang Wen, Lei Guangyong: political shock, uncertainty and corporate cash holding, Nankai management review, 2015, issue 4.

Jin Zhi: communication among officials in different places, demands for political achievements and selection of accounting policies of the company, accounting research, 2013, issue 11.

Lin Yifu: the tide phenomenon and the reconstruction of macroeconomic theory in developing countries, economic research, 2007, issue 1

Pan Yue, Ning Bo, Xiao Jinli: the transfer of local political power and the reconstruction of the relationship between government and enterprise - Evidence from the replacement of local officials and the change of senior executives, China industrial economy, 2015, issue 6.

Wang Xianbin, $\mathrm{Xu}$ Xianxiang and Li Ying: local management replacement and economic growth, Economics (quarterly), 2009, issue 4.

Xia Lijun and Chen Xinyuan: the process of marketization, the strategy of SOE reform and the endogenous decision of corporate governance structure, economic research, 2007, issue 3.

Xu yekun, Qian xianhang, Li Wei'an: political uncertainty, political connection and private enterprise investment Evidence from the replacement of municipal Party Secretary, management world, 2013, issue 5.

Yang Haisheng, Luo danglun, Chen Shaoling: resource endowment, official exchanges and economic growth, management world, 2010, issue 5.

Zhang Dunli and Jiang Xinfeng: management ability and herd behavior in Enterprise Investment: the regulatory role based on compensation equity, accounting research, 2015, issue 5.

Zhang Ersheng and $\mathrm{Hu}$ guoliu: personal characteristics of local officials and the upgrading of regional industrial structure: Based on the analysis of the Secretary of the CPC Provincial Committee and the governor of the province, China soft science, 2013, issue 6.

Zhang Ersheng: the enterprise background and economic growth of local officials - Evidence from the Secretary of the CPC Provincial Committee and the governor of the province, China industrial economy, No. 31, 2010.

Zhang Jun, Gao Yuan: term of office of officials, communication in different places and economic growth - Evidence from provincial experience, economic research, 2007, Issue 9.

Zhou Li'an: Research on the promotion championship mode of local officials in China, economic research, 2007, issue 7. 